\title{
Youngest record of the extinct walrus Ontocetus emmonsi from the Early Pleistocene of South Carolina and a review of North Atlantic walrus biochronology
}

Sarah J. Boessenecker, Robert W. Boessenecker, and Jonathan H. Geisler

Acta Palaeontologica Polonica 63 (2), 2018: 279-286 doi:https://doi.org/10.4202/app.00454.2018

The extinct North Atlantic walrus Ontocetus emmonsi is widely reported from Pliocene marine deposits in the eastern USA (New Jersey, Florida), Belgium, Netherlands, Great Britain, and Morocco. Ontocetus was slightly larger than the modern walrus Odobenus rosmarus , may have had wider climatic tolerances (subtropical), and likely originated in the western North Pacific before dispersing through the Arctic. Owing to geochronologic uncertainties in the North Atlantic Plio-Pleistocene walrus record, it is unclear whether Ontocetus and Odobenus overlapped in time and thus may have competed, or whether the two were temporally separate invasions of the North Atlantic. A new specimen of Ontocetus emmonsi (CCNHM-1144) from the Austin Sand Pit (Ridgeville, South Carolina, USA) is a complete, well-preserved left tusk that is proximally inflated and oval in cross-section, relatively short (maximum length: 369 $\mathrm{mm}$ ) and markedly curved (radius of arc of curvature $197 \mathrm{~mm}$ ). Globular dentine is present, confirming assignment to Odobenini; proportions and curvature identify the specimen as Ontocetus emmonsi rather than Odobenus. Hitherto unstudied deposits in the Austin Sand Pit lack calcareous macro and microinvertebrates, but vertebrate biochronology provides some temporal resolution. The co-occurrence of a giant beaver (Castoroides sp.) and a snaggletooth shark (Hemipristis serra) indicate an age of 1.1-1.8 Ma (Early Pleistocene) and correlation with the Lower Pleistocene Waccamaw Formation. The vertebrate assemblage is named the Ridgeville Local Fauna. The composition of the marine mammal assemblage from the Austin Sand Pit is intermediate between that of the lower Pliocene Yorktown Formation (North Carolina, USA) and the modern North Atlantic fauna. This record reported here is the youngest of Ontocetus emmonsi from the Atlantic Coastal Plain. A review of North Atlantic Plio-Pleistocene walrus records reveals no overlap between extinct Ontocetus and extant Odobenus — suggesting independent dispersal to the North Atlantic and a lack of competition.

Key words: Mammalia, Carnivora, Odobenidae, Ontocetus, Odobenus, Pliocene, Pleistocene, North Atlantic. 
USA.; School of Museum Studies, University of Leicester, Leicester LE1

7RF, UK. Robert W. Boessenecker [boesseneckerrw@ cofc.edu] (corresponding

author), Department of Geology and Environmental Geosciences, College of

Charleston, Charleston, South Carolina, 29424 USA; University of California

Museum of Paleontology, Berkeley, California, 94720 USA. Jonathan H. Geisler [jgeisler@nyit.edu],

Department of Anatomy, New York Institute of Technology, Old Westbury, New York 11568-8000

USA.

This is an open-access article distributed under the terms of the Creative Commons

Attribution License (for details please see creativecommons.org), which permits unrestricted use,

distribution, and reproduction in any medium, provided the original author and source are credited.

FoF Full text $(232.7 \mathrm{kB})$ ।

For 5 Supplementary file $(143.3 \mathrm{kB})$ 